University of Nebraska - Lincoln

DigitalCommons@University of Nebraska - Lincoln

9-1989

\title{
Biology and Characterization of Prodiplosis Longifila (Diptera: Cecidomyiidae) on Lime in Florida
}

\author{
J. E. Pena \\ University of Florida \\ Raymond Gagne \\ ARS \\ R. Duncan \\ University of Florida
}

Follow this and additional works at: https://digitalcommons.unl.edu/systentomologyusda

Part of the Entomology Commons

Pena, J. E.; Gagne, Raymond; and Duncan, R., "Biology and Characterization of Prodiplosis Longifila (Diptera: Cecidomyiidae) on Lime in Florida" (1989). USDA Systematic Entomology Laboratory. 15. https://digitalcommons.unl.edu/systentomologyusda/15

This Article is brought to you for free and open access by the Entomology Collections, Miscellaneous at DigitalCommons@University of Nebraska - Lincoln. It has been accepted for inclusion in USDA Systematic Entomology Laboratory by an authorized administrator of DigitalCommons@University of Nebraska - Lincoln. 
This article is a U.S. government work, and is not subject to copyright in the United States.

\title{
BIOLOGY AND CHARACTERIZATION OF PRODIPLOSIS LONGIFILA (DIPTERA: CECIDOMYIIDAE) ON LIME IN FLORIDA
}

\author{
J. E. Peña ${ }^{1}$, Raymond J. GaGnÉ ${ }^{2}$, And R. DUnCAN ${ }^{1}$ \\ ${ }^{1}$ University of Florida, IFAS \\ Tropical Research and Education Center \\ 18905 S.W. 280 Street, Homestead, F'lorida 33031 \\ 2Systematic Entomology Laboratory \\ Agricultural Research Service \\ USDA c/o U.S. National Museum NHB 168 \\ Washington, D.C. 20560
}

\begin{abstract}
Prodiplosis longifila Gagné (Diptera: Cecidomyiidae) is a polyphagous, Neotropical species with a known range that extends into southern Florida. This gall midge feeds on the flower ovaries of lime and can cause premature flower abscission. Details of its biology on lime are given, the life stages illustrated, and the three larval instars described in detail.

\section{RESUMEN}

Prodiplosis longifila Gagné (Diptera: Cecidomyiidae) es una especie polifaga y neotropical y su rango se extiende hasta el sur de la Florida. Esta mosquita destruye los ovarios de las flores de los limones y puede causar caida prematura de las flores. Se dan detalles sobre su biología en los limones, se hacen ilustraciones de los differents estados, y se describen los tres estadios larvarios.
\end{abstract}

Prodiplosis longifila Gagné was recently reported feeding in flowers of lime, Citrus aurantifolia (Christm.) Swingle (Rutaceae), in Dade and Collier Counties, Florida (Peña et al. 1987). Larvae completely destroy the ovaries of the flowers and may cause premature flower abscission. The only previous record of this species from the United States was from wild cotton, Gossypium sp. (Malvacea), from Monroe Co., Florida (Gagné 1986). Prodiplosis longifila is otherwise known from Colombia and Peru, where it is known to be a pest of tomatoes, potatoes, alfalfa, and other commodities (Gagné 1986). 
In this report we present the first known details of the life history of $P$. longifila on lime and describe the larval instars.

\section{Methods}

The biology of $P$. longifila was studied in a 0.7 ha, 10-yr old 'Tahiti' lime orchard in Homestead, Florida and in the laboratory at the Tropical Research and Education Center, Homestead, Florida. Approximately 30 trees were used in this study. Observations were made over a period of 86 days (November 1987 through January 1988) for five generations of the gall midge.

Lime flowers in their first stages of development (less than $1 \mathrm{~mm}$ in diameter) were bagged with nylon mesh. Flowers were left exposed for $12 \mathrm{~h}$ and egg masses collected after females oviposited. Egg masses $(n=14)$ were transferred to the laboratory and eggs $\mathrm{n}=258)$ placed individually in petri dishes $(5.2 \mathrm{~cm}$ in diameter) lined with filter paper. Petri dishes were held at $27^{\circ} \mathrm{C}$ and $84 \pm 2 \mathrm{RH}$ and observed daily. After eclosion each larva was removed and transferred to similar petri dishes with excised flowers. Larvae were removed two times during the day to determine the duration of each instar. Full-grown larvae from a set of infested flowers were allowed to drop into one of $12360 \mathrm{ml}$ carton containers, each containing $400 \mathrm{~g}$ of previously sterilized 'Rockdale' soil. Pupae were collected from the soil surface and from different soil depths (1.5-2.9 $\mathrm{cm}, 3.0-5.4 \mathrm{~cm}$, and $5.5-8.0 \mathrm{~cm}$ ). Adult emergence was determined in the field by placing infested flowers on plastic containers $(43 \times 59 \times 26 \mathrm{~cm})$ filled with 'Rockdale' soil. Clear-plastic circular plates ( $24 \mathrm{~cm}$ diam.) coated with Tanglefoot $B$ were placed on top of the containers. Adults trapped on the plastic plates were counted every $2 \mathrm{~h}$ during a $24 \mathrm{~h}$ period on five separate days (November 19, 20, 21, 1987 and January 14, 15, 1988). Adults kept in the laboratory were maintained in a rearing chamber at $27^{\circ} \mathrm{C}$ and $84 \pm 2 \mathrm{RH}$ with ca. $12 \mathrm{~h}$ photoperiod. Each adult was kept in a petri dish lined with filter paper and provided with ca. $0.01 \mathrm{ml}$ of honey and $0.01 \mathrm{ml}$ water or left without food.

Larvae used for detailed descriptive study were mounted on glass slides in Hoyer's mounting medium or Canada balsam for study. Measurements were made of 20 specimens of each instar. Representative specimens have been deposited in the National Museum of Natural History, Washington, D.C.

\section{Results AND Discussion}

Eggs are transparent, elongate-ovoid, $0.265 \pm 0.035 \mathrm{SE} \mathrm{mm} \times 0.096 \pm 0.002 \mathrm{SE} \mathrm{mm}$ (Fig. 2). They are deposited on stamens or styles, usually of flowers that are $0.46-0.65$ $\mathrm{cm}$ in diameter $\left[\mathrm{x}^{2} .05[8] ; \mathrm{P}<0.05\right]$ or in flowers in which a small opening in the corolla allows the style to protrude. One to $59 \mathrm{eggs}$ (mean $=12.6 \pm 2 \mathrm{SE}$ ) were found per infested flower under laboratory conditions. Larvae hatched in $1.4 \pm 0.045 \mathrm{SE}$ days.

Larvae are almost transparent when newly eclosed, turn white 1.2 days later and become yellowish to orange when full-grown (Fig. le). There are three instars. Major anatomical features common to all three (Figs. 5-13) are a small head capsule with one-segmented, conical antennae, a neck segment, three thoracic segments, and nine abdominal segments, each segment with papillae characteristic for the Cecidomyiini in number and position (Gagné in press). The spiracles of the eighth abdominal segment are situated posteriorly.

The first instar (Figs. 5-7) ranges from $0.40-0.92 \mathrm{~mm}$ in length. The head capsule is $0.045 \pm 0.003 \mathrm{~mm}$ wide at the posterior end. This instar has only one pair of spiracles, on the eighth abdominal segment (Fig. 5), and that is the most conspicuous difference between this instar and the remaining two.

The second instar (Figs. 8-10) ranges from 0.76-1.85 mm in length. The head capsule 


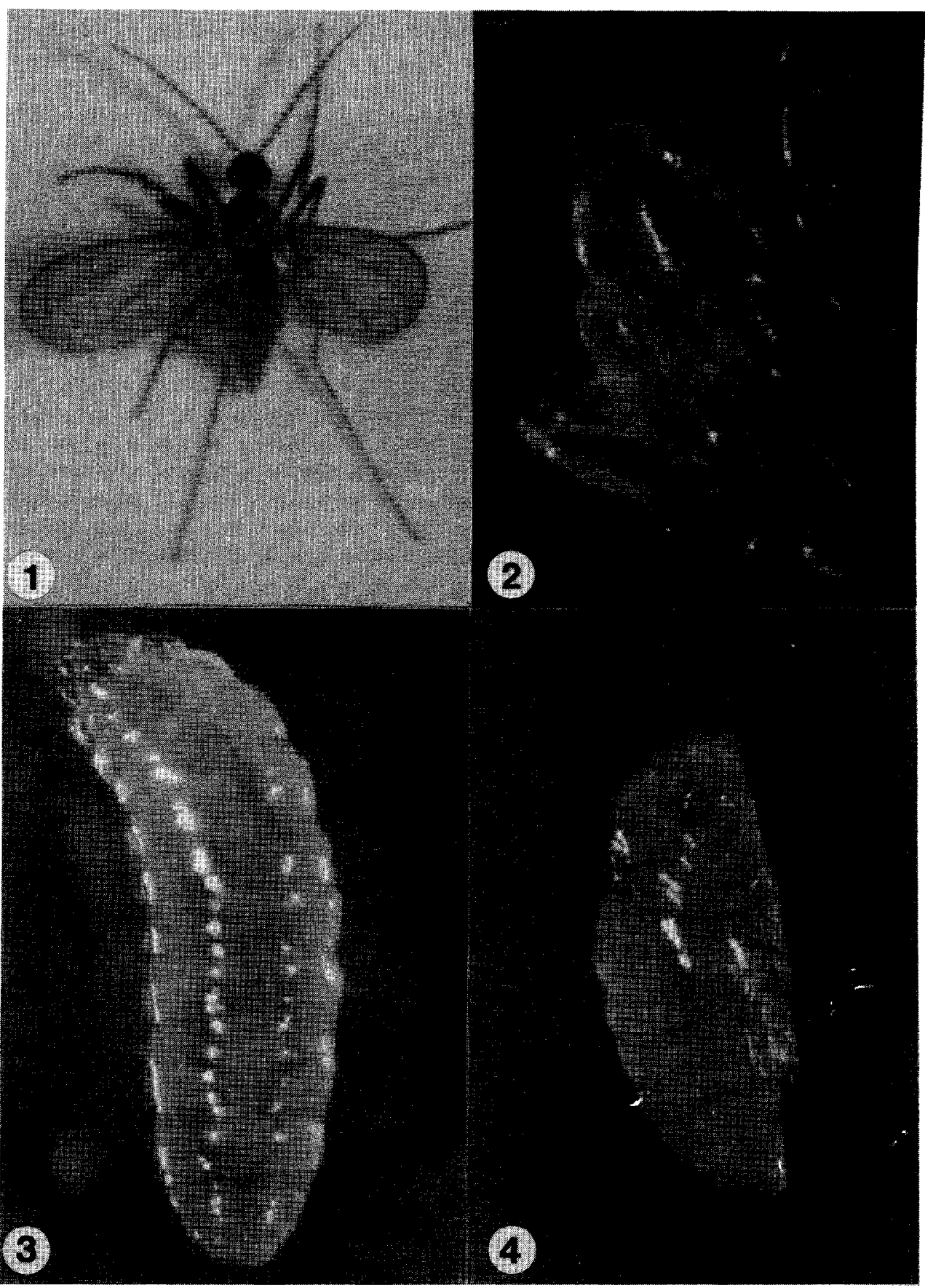

Fig. 1-4. Prodiplosis longifila. 1, adult. 2, eggs. 3, third instar. 4, pupa.

is $0.050 \pm 0.005 \mathrm{~mm}$ wide at its posterior end. This instar has the full complement of spiracles for cecidomyiid larvae, one pair on the first thoracic segment and one pair on each of the first through eighth abdominal segments. It differs from the third instar in lacking a spatula and having the corniform pair of papillae on the terminal segment less strongly developed relative to the other three pairs. 


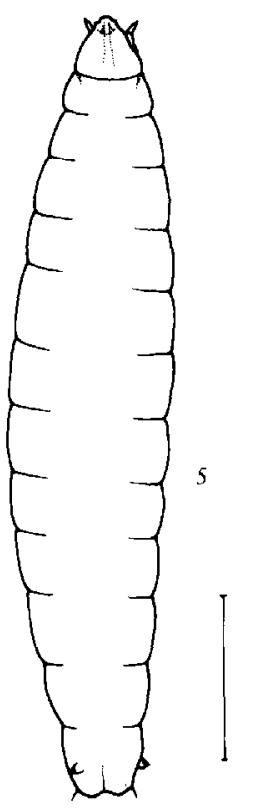

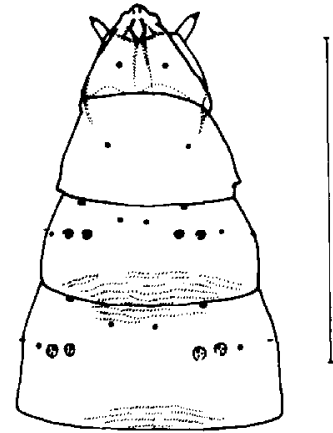

6
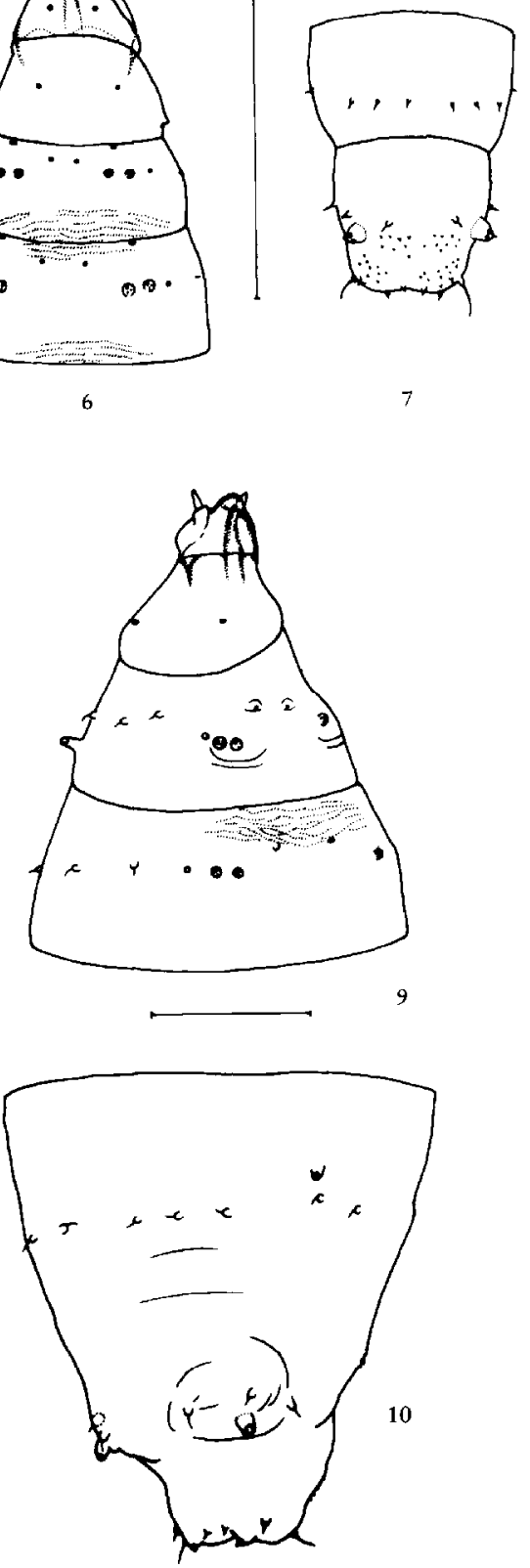

Figs. 5-10. Larvae, Prodiplosis longifila. 5-7, First instar: 5, dorsal view; 6, head through second thoracic segment, ventral; 7 , abdominal segments seven through nine, dorsal. 8-10, Second instar: 8, dorsolateral view; 9, head through second thoracic segment, ventrolateral; 10, abdominal segments seven through nine, dorsolateral. Line = $0.1 \mathrm{~mm}$

The third instar (Figs. 11-13) ranges from 1.15-1.90 mm in length. The head capsule is $0.050 \pm 0.005 \mathrm{~mm}$ wide at its posterior end. The spiracular system is similar to that of the second instar. The distinguishing feature of this instar is the clove-shaped spatula on the venter of the first thoracic segment (Fig. 12). The papillar setae, except for those 

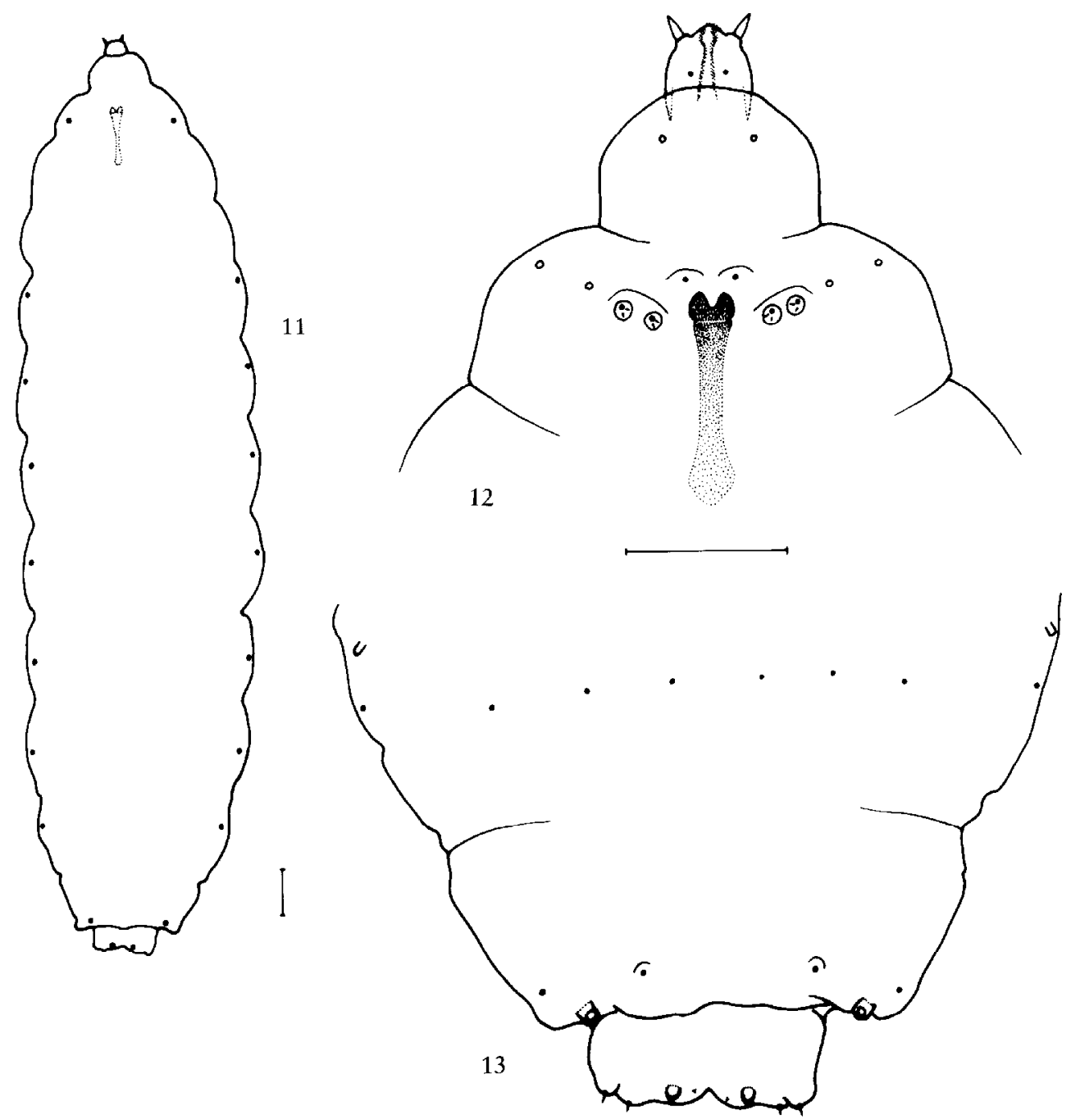

Figs. 11-13. Third instar, Prodiplosis longifila. 11, dorsal view with the ventral spatula dotted in to show relative size and position; 12, head through first thoracic segment, ventral; 13, abdominal segments seven through nine, dorsal. Line $=0.1 \mathrm{~mm}$.

of the terminal segment, are shorter relative to the width of the papillar bases than in previous instars.

The head capsule width of cecidiomyiid larvae usually becomes significantly larger in each instar (Gagné and Hatchett in press, Roskam 1977, 1979, Wilson 1966), but in $P$. longifila the head of the second instar is as wide as that of the third. First instar head capsules are sometimes also as wide as those in following instars. Antennae are similarly shaped in each instar.

Two days after hatching, 17 of 20 larvae collected were first instar, three were second instars. Three days after hatching, 12 of 20 larvae were second instars and eight were third instars. Four days after hatching all larvae were third instars. The entire larval stage last $9 \pm 1.63$ days.

Larvae feed on the surface of the ovary, pistils, and stamens of lime flowers. One to 66 larvae were found per infested flower $(24.26 \pm 4.15 \mathrm{SE})$. Mature larvae drop to the ground, where they penetrate the soil more frequently at a depth of $1.5 \mathrm{~cm}$ than at 


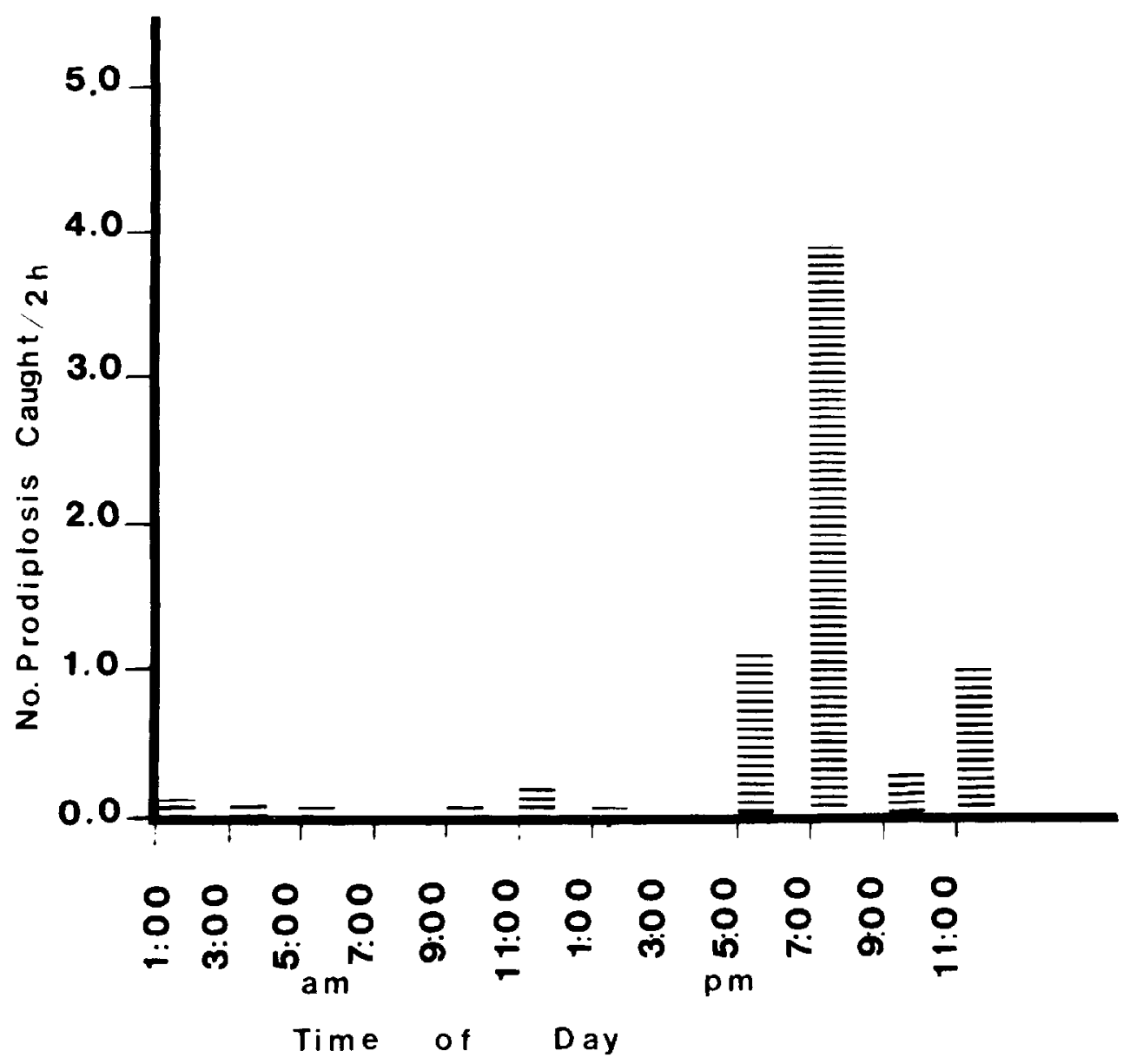

Fig. 14. Average daily catches of Prodiplosis longifila adults every two $h$.

other depths $\left(\chi^{2} .005[3]=7.81 ; P<0.005\right)$. They then spin a white cocoon, which sometimes incorporates sand grains.

Pupae are 0.85-1.00 mm long and pale yellow when newly molted (Fig. 4). The head and thorax turn black $3.02 \pm 0.92 \mathrm{SE}$ days later. This stage lasted $4.11 \pm 1.22 \mathrm{SE}$ days unless parasitized.

Adults are about $1.5 \mathrm{~mm}$ in length (Fig. 1). Wing length is $1.42 \pm 0.04 \mathrm{~mm}$ in males, $1.53 \pm 0.02 \mathrm{~mm}$ in females. A technical description of this stage is given in Gagné (1986). Peak emergence occurred between 1700 and 2300 hours, but a few adults emerged at other times (Fig. 14). Temperatures recorded during periods of adult activity ranged from $17-20^{\circ} \mathrm{C}$. Relative humidity ranged between $69-98 \%$. The female to male sex ratio of emerging adults fluctuated between $70: 30$ and 50:50 $(n=87-40)$. Adults reared in the laboratory survived $1.06 \pm 0.24$ days if not fed; if held in vials with available honey and water, they survived $8.30 \pm 1.21$ days, with a maximum of 16 days.

Prodiplosis longifila is parasitized by Synopeas sp. (Platygasteridae), an egg-larval parasitoid. Parasites emerged 14-16 days after pupation of the gall midge.

\section{ACKNOWLEDGMENTS}

We thank Deborah Leather Roney, Arlington, Virginia, for the detailed larval draw- 
ings and L. Stange, Florida Department of Agriculture and Consumer Services, Division of Plant Industry, Gainesville, for identifying the parasitoid of $P$. longifila. We are grateful to R. M. Baranowski, University of Florida, Homestead, P. E. Boldt, Agricultural Research Service, USDA, Temple, Texas, N. E. Woodley, Agricultural Research Service, USDA, Washington, D.C., H. C. Roskam, University of Leiden, The Netherlands and L. F. Wilson, East Lansing, Michigan for commenting on a draft of the ms. The work was supported by a grant from the Florida Lime and Avocado Committee. This paper is Florida Agricultural Experiment Station Journal Series No. 9573.

\section{References Cited}

Gagné, R. J. 1986. Revision of Prodiplosis (Diptera: Cecidomyiidae) with descriptions of three new species. Ann. Entomol. Soc. Am. 79: 235-245.

- In press. The plant feeding gall midges of North America. Cornell University Press, Ithaca, New York.

GAGNÉ, R. J. AND J. H. HATChETT. In press. Larval instars of the Hessian fly (Diptera: Cecidomyiidae). Ann. Entomol. Soc. Am.

Peña, J. E., R. M. Baranowski, and R. T. McMillan, JR. 1987. Prodiplosis longifila (Diptera: Cecidomyiidae) a new pest of citrus in Florida. Florida Entomol. 70: 527-529.

RoskaM, H. C. 1977. Biosystematics of insects living in female birch catkins. I. Gall midyes of the genus Serrudulia Kieffer (Diptera: Cecidomyiidae). Tijdschr. Entomol. 120: 153-197.

1979. Biosystemtics of insects living in female birch catkins. II. Inquiline and predaceous gall midges belonging to various genera. Netherlands J. Zool. 29: 283-351.

Wilson, L. F. 1966. Life history, habits, and damage of the boxelder leaf gall midge, Contarinia negundifolia Felt (Diptera: Cecidomyiidae) in Michigan. Canadian Entomol. 98: 777-784. 


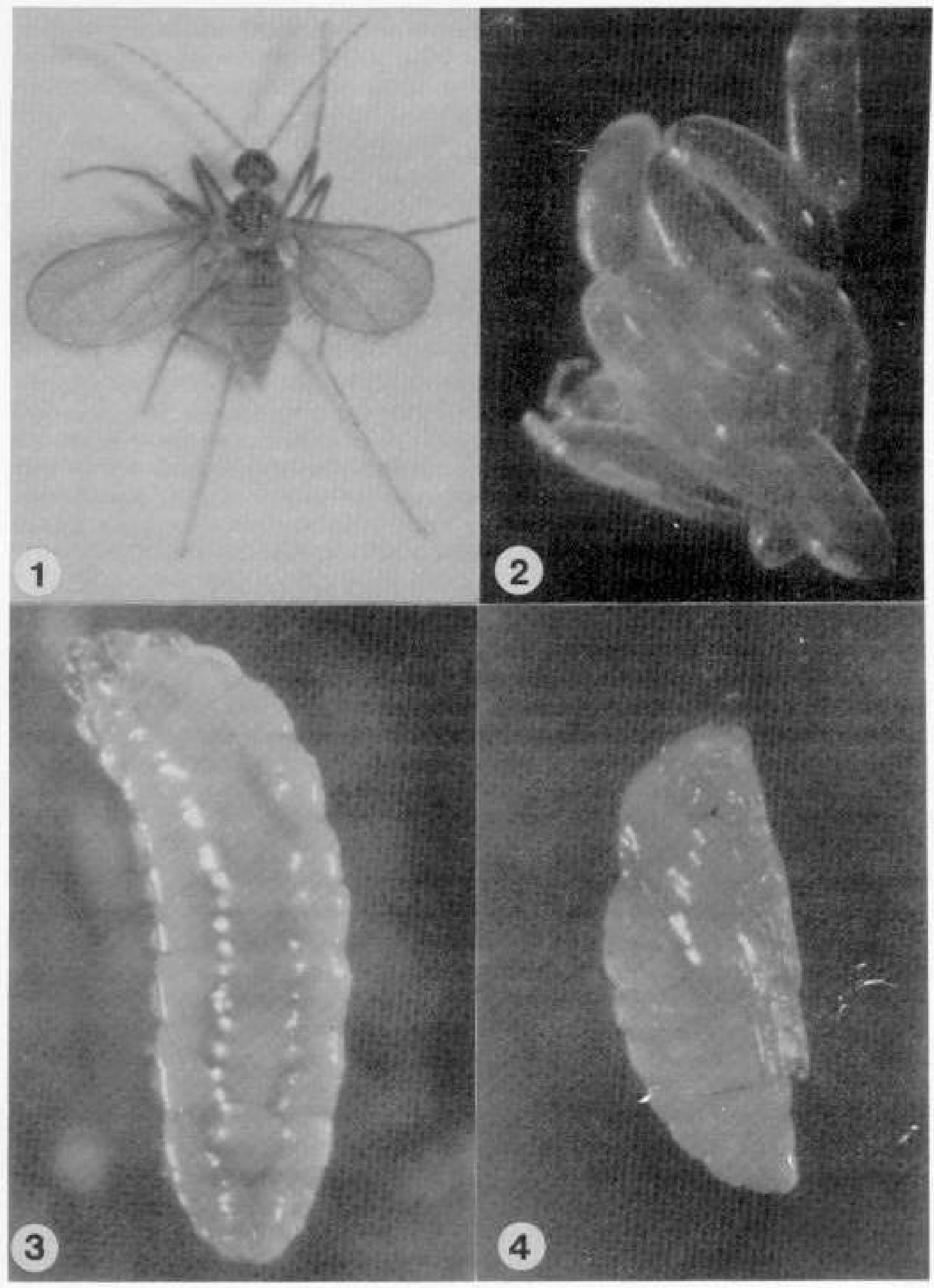

